\title{
SGPP2 Gene
}

National Cancer Institute

\section{Source}

National Cancer Institute. SGPP2 Gene. NCI Thesaurus. Code C105043.

This gene plays a role in sphingosine-1-phosphate catabolism. 